\title{
Santri Education Problems at Darul Huffadh Islamic Boarding School in Bone Regency, Sulawesi Selatan, Indonesia
}

\author{
Muhammad Syukur* \\ Departmen of Sociology Education \\ Faculty of Social Science \\ Universitas Negeri Makassar \\ Makassar, Indonesia \\ m.syukur@unm.ac.id
}

\author{
Rifal \\ Departemen of History Education \\ Faculty of Social Science \\ Universitas Negeri Makassar \\ Makassar, Indonesia \\ rifalmattirodeceng@gmail.com
}

Fitrah Widyawati

Departemen of History Education

Faculty of Social Science

Universitas Negeri Makassar

Makassar, Indonesia

widyafitrah@gmail.com

\author{
Amirullah \\ Departemen of History Education \\ Faculty of Social Science \\ Universitas Negeri Makassar \\ Makassar, Indonesia \\ Amirullah8505@unm.ac.id
}

\begin{abstract}
This article discusses the problem of santri education in Darul Huffadh Islamic Boarding School in Bone Regency. The main problem experienced by santri when they finished boarding school was how they could use their knowledge for the lives of the general public. In general, the students after they finished their pesantren immediately became preachers in their respective regions. When students become students they are not ready to interact with others but because when the child arrives to eat there is a culture shock because the child does not understand or does not know that there is a strange culture out there that is owned by his friends, this can affect the mental the child, the child may be inferior, but the child can also adjust if the level of culture shock can be overcome by himself. In the process of socialization, adolescents learn the values, norms and roles in their society. By understanding the values and norms and being able to take a role in society, it shows that the teenager has a good level of conformity because he is able to behave in accordance with social expectations. This research is an anthropological sociology study using a qualitative approach. Data obtained through interviews combined with secondary data relevant to the research theme. Furthermore, research that describes the situation or situation that will be examined based on data obtained in accordance with the problems specified in the research.
\end{abstract}

Keywords: Problematics, Santri, Islamic Boarding School Darul Huffadh

\section{INTRODUCTION}

Every family has its own perspective on the values they uphold, whether it is based on a sense of tribal culture or not. Parents are the main guides in the family for children to do cultural learning. Every family has a special way of managing the values that members carry out in accordance with the culture that they also uphold.

That is not an impossible thing that will happen. The development of technology and information that is accompanied by Western cultural values will eventually erode the values of Islam that have taken root in society. As experience experience globalization. While negative culture is increasingly dominant with rampant gambling, liquor (alcohol), and prostitution. The impact is that the local people do not have enough strength to resist the entry of foreign culture into a negative image in their community and will gradually change local Islamic traditions to those that are more directed towards foreign cultures. It may be that later, the Pasuruan community, who usually after the Maghrib Prayer, recite the Qur'an and Wiridan, after undergoing industrialization, perform entertainment activities that are far from Islamic values [1].

Many children who have problems or are affected by the environment because enculturation in the family is not conducive. The occurrence of sexual violence, physical violence and the emergence of wrong behavior in children, such as brawls, skipping school, joining motorcycle gangs and using drugs because the element of education in the family is not going well. Or simply can be said that the success of children in social relations with the community depends on the pattern of parenting to their children.

The next problem that may arise is when a child who is not going through the maximum enculturation process then he is not ready to interact with others but because when the child has arrived there is a culture shock because the child does not understand or does not know that there is a strange culture out there that is owned for example by his friends, this can affect the mentality of the child, the child may be inferior but the child can also adjust if the level of culture shock can be overcome by himself.

Facts in the community show that not a few pesantren children are 'damaged' when outside the pesantren or immediately after graduating from pesantren which may be the cause is due to lack of optimal attention received in the family. They become a generation that is vulnerable to the temptations of the world. The results of immunity that are expected by parents through a sterilization program (coercion, including pesantren) are far from fire. For this reason, this research is here to uncover the problems of pesantren education in Darul Huffadh.

\section{METHOD}

This research uses a descriptive type qualitative approach. Bogdan and Taylor define qualitative 
methodology as a research procedure that produces descriptive data in the form of written or oral words from people and observed behavior [2]-[5]. The place of research is the object and source of data from a careful place so that the information obtained can provide accurate data and truth in research. In this study took location in the Regency of Bone precisely in the Environment Boarding School Darud Huffadh or commonly referred to as the Pesantren Tujutuju. Primary data sources are data obtained directly from informants through interview techniques or interviews. The informants of this study the researchers used purposive sampling. purposive sampling is a research technique used by researchers based on the criteria desired by researchers. The criteria for informants in the study, namely: a) Santri boarding school Darud Huffadh Bone, b) Aged 13-16 years.

Secondary data sources are data obtained that are consistent with this study. Data sources in the form of documents, books, journals, archives, theses and statistical data published by the government or private sector relating to this research. Data analysis in this research was carried out since before entering the field, during the field, and after completion in the field.

Data obtained from the field are then processed descriptively qualitatively through three stages, namely data reduction, data presentation and drawing conclusions. Data Reduction, Data obtained from the field with a considerable amount, for that it needs to be recorded carefully and in detail. Data reduction is an activity that summarizes, selects and focuses on important things, looking for themes and patterns. Data Presentation, After the data has been reduced, the next step is the presentation of data (data display). Through the presentation of these data, the data is organized, arranged in related patterns, so that it will be more easily understood. In qualitative research, the presentation of data can be done in the form of brief descriptions, charts, relationships between categories, flowcharts and the like. Withdrawal of Conclusions, after making the data reduction then make conclusions. Conclusions are drawn to answer the problem formulation that was formulated from the beginning.

\section{RESULT AND DISCUSSION}

Before explaining more about the problems of students in receiving enculturation from their parents, schools and madrasas should first be known that education as a system consists of a number of components. These systems consist of instrumental inputs, raw inputs, inputs, processes, outputs, environmental, and outcomes. Each component has a specific function and jointly carry out the function of the structure, which is to achieve the objectives of the system [6]. But in this discussion, these components are identified in the education system in the form of inputs, processes and outputs [7].

Inputs to the education system are divided into three types, namely raw input, instrument input (instrumental input), and environmental input. Raw inputs will be processed into graduates (output) and the main inputs in the education system are the basis of education, educational goals, and students or students. While the educational process is the mobilization of all components of education by educators directed to the achievement of educational goals. The quality of the educational process is symptomatic of two aspects, namely the quality of components and the quality of their management. Both aspects are interdependent. The components that are mutually sustainable in the education process include: educators and non-educators, curriculum (educational material), infrastructure and facilities, administration, and budget. Then the last output in the education system is the output of the process that occurs in the education system. The outputs in the education system are: graduates (graduates) and dropouts [7]. The problem referred to in this study is when they become santri and after finishing studies from pesantren.

The first thing experienced is family. The family is a small social group consisting of father, mother and child [8]. The family has an important function in the social system in society because the family is the place for the first socialization of individuals as social beings. Therefore, the family wherever and however its shape is the most important environment in the development of a child. In the clerical family, as in other forms of family is the media or a place where a child begins to learn and get to know the outside world. So, this child's development is influenced by how parents educate and care for their children [9].

Parents have their own way of guiding children. The way one family is different from another, Parenting is a picture of the attitudes and behavior of parents and children in interacting, communicating during holding parenting activities [10]. In the activities of providing care, parents will provide attention, regulations, discipline, gifts and punishment, as well as responses to the wishes of their children. Attitudes, behaviors, and habits of parents are always seen, valued, and imitated by their children who then consciously or unconsciously absorb it and then become a habit for their children [8]. The main problem experienced by santri when they finished boarding school was how they could use their knowledge for the lives of the general public. In general, the students after they finished their pesantren immediately became preachers in their respective regions. Santri, as he was a teenager, experienced a period of developmental transition between childhood and adulthood which involved biological, cognitive and socio-emotional transformation to prepare himself for adulthood and the future. While relating to this socio-emotional change, students must adapt to people outside their family, such as peers or other significant others. In this view, Hurlock states that because adolescents are more out of the house with peers as a group, it is understandable that the influence of peers on attitudes, talks, interests, appearance and behavior is greater than the influence of family [11].

Peer groups or any group that is followed by adolescents usually have two things that are generally shared by other groups, namely norms in the form of rules that apply to all members of a group and roles that constitute certain positions in a group created based on rules and expectations [12]. The negative role of the conformity shows the existence of antisocial behavior where the community at present from the village to the city faces a problem where children tend to address antisocial behavior earlier. This behavior disorder can be described as a pattern of chronic behavior in which a person violates the norms of society according to his age and disturbs the rights of others [13]. such as stealing, cheating, cheating during school exams, vandalism, often truant and other behaviors that are not in accordance with prevailing social norms. From this group of peers, teens receive feedback about their abilities. Teenagers learn about whether what they are doing is better, as good or even worse than what other teenagers are doing [12]. 
In the world of pesantren, students included in the category of adolescents are students who are categorized as ages around 12-20 years [14]. Santri is also a teenage figure who has a strong sense of brotherhood among peers. This is in addition to the existence of religious doctrine to always maintain ukhuwah Islamiyah as well as the lives of santri away from parents who require them to live together in their peers in pesantren. The role of peers in the santri world cannot be ignored because peers have the main function of which is to provide information about the world outside the family. But on the other hand, when students must return to the community where they live, they have difficulty in behaving and behaving in accordance with social norms and rules that apply in society because there are differences with the norms and rules that apply in pesantren. As a result, students who are unable to behave and behave according to community standards, feel inferior and withdraw from their social. This shows the low level of santri conformity. Whereas a santri is educated independently in his pesantren and is expected to be able to play a role in dealing with social problems in his environment. It is even expected to become a person who has a deep knowledge of Islam and can teach and apply it in the life of the community where the students return after completing their studies at the pesantren [15].

Santri who have finished school in their pesantren will return to their parents and community, Muhammad Fatur revealed after they returned home, they were faced with a different culture in East Nusa Tenggara, they returned to farming and working everyday in social life, but in life religiously, they often get invitations to appointments, lectures and mosque imams [16]. Furthermore, Fatur told that after many changes had taken place, the activities in the religious social field had increased. There are some people who call to be teachers of the Koran, inviting to always come to his house. Now I am the imam of a mosque in East Nusa Tenggara, in addition to making study classes attended by children and young people free of charge. In accordance with the motto of Pesantren Darul Huffadh which is always expressed by KH. Lanre Said, remain a candle in the dark. This phenomenon is often found in other places, such as several other areas in the east, such as Kupang, Bima and Sabu. There are quite a number who continue their education, both private and public.

When students enter the social environment and establish relationships with the community, they will experience real or imagined demands or pressures to behave in accordance with applicable social norms and values. The demand requires them to understand the identity of the ego which is a feeling of who he is and what his place is in the larger social order [17]. This shows that self-concept helps adolescents to understand the social environment and guidelines for future behavior [18], and to understand and understand social values and norms prevailing in society is included in students' understanding of their social environment, making it easier for adolescents to behave conformity in social life. It has been explained before, that pesantren are educational institutions that teach morality and morality, because in them apply six methods of humanitarian learning, including: (a) exemplary (uswah hasanah); (b) training and habituation; (c) take lessons (ibrah); (d) advice (mauidzah); (e) discipline; (f) praise and punishment (tadghib wa tahzib) and independence [19].

Parents sometimes mistakenly interpret the role of Islamic boarding schools so that after their children are registered and live in boarding schools, the parents are obliged to release their children, even though boarding schools are not workshops or places that are ready to print nice and neat, because their roles are very small compared to parents and homes (families), without the support of parents, very little results obtained by children who study in Islamic boarding schools. Many assumptions and perceptions from parents if they have registered their children in boarding schools, then we as parents can receive good results. False assumptions like this will only create a mentality of parents who are too trusting so that it loses a sense of conscience in the development of children. In essence, a child is a gift of God that cannot be judged by anything. It is a place of love for parents. But as the child grows older, a new "agenda of problems" emerges that never ends. When children get older they can show a sweet and polite face, full of filial piety to parents, excel in school, get along well with their community environment, but on the other hand can also vice versa. His behavior is getting out of control, the shape of delinquency is turning into crime, and parents are always worried about it [20].

Problems that can arise during children studying in Islamic boarding schools are mostly about the adjustment of children or students to the rules or qanun in the boarding school environment, namely the phenomenon of not being able to adapt to the environment of Islamic boarding schools, non-compliance with applicable regulations, and some behaviors who break the rules to satisfy the curiosity of all things, for example the feeling of wanting to try smoking in boys, and there are regulations that require boarding schools that are not allowed to get out of the boarding school environment except holidays. These things can cause children to become bored with routine learning activities in Islamic boarding schools which tend to be monotonous so that children can deliberately break the rules by not following existing activities or deliberately leaving the boarding school environment for refreshing. There are more problems experienced by children who study in Islamic boarding schools related to personal issues including: feeling not "at home" or at home in boarding schools because it can be learned in the boarding school is not their own choice, often disturbed by other children or students, feel miss or miss parents because they haven't seen each other for a long time, or shipments (pocket money or food) from parents arrive late or are delivered late at the boarding school. It needs to be realized here, no matter how severe these obstacles are, parents should be patient and make these obstacles as challenges and tests [20].

In educating children there are at least two kinds of challenges, one internal and the other external. Both of these challenges greatly affect children's development. The main source of internal challenges is the parents themselves. Many parents who do not hesitate to blame the boarding school if their children are found not upgrade, or are expelled because of violations of the discipline of the cottage. Among parents there are those who are not ready to accept the news of their child's failure, or other bad news about their children, or their children's report cards have a lot of red numbers. They put too much trust in their children with consideration and analysis of the past. So that such parents are always suspicious of bad news about their children. Though boarding school is not a place that is ready to repair all the damage that exists in children. Should parents always instill attention and motivation for the success of their baby. Children who do not get support from their parents will most likely get various problems in their 
lives and children who are not cared for by their parents will try to seek support from outside the support of their parents. Good parental support in the form of feelings of acceptance, belonging, and love that comes from parents to children can be in the form of assistance, comfort, attention, and appreciation where parental support can greatly influence the behavior and emotions of children while studying in Islamic boarding schools in achieving their goals. Added by Katz (1997) that children who get support and assistance from their parents will be able to learn to progress better than children who do not get support and assistance. Many studies have shown that parents who support their children personally will have an infinite effect of magnitude [20], [21].

In the process of learning children in Islamic boarding schools need the support of their parents. Parental support can include moral support in the form of attention to the fulfillment of psychological needs which include love, example, guidance and direction, encouragement, enthusiasm, motivation, and instill confidence, where parental attention is the hope of all children in their growth and development. Parental spiritual support, for example, always pray for and foster mental development of children, so that their children in the learning process are given ease in achieving their success so as to obtain good achievements. Whereas parental support in the form of material concerns the economic situation of parents which can be used for educational expenses and to supplement their daily equipment and learning equipment for the continuity of their education from beginning to end [19], [20], [22]. The success of students in understanding the values and social norms that apply is not only influenced by the self-concept that is owned, but parenting parents also become one of the factors that help the success. This can be seen from the process of socialization of adolescents in the care process. In the process of socialization, adolescents learn the values, norms and roles in their society. By understanding the values and norms and being able to take a role in society, it shows that the teenager has a good level of conformity because he is able to behave in accordance with social expectations.

\section{CONCLUSION}

The main problem experienced by santri when they finished boarding school was how they could use their knowledge for the lives of the general public. In general, the students after they finished their pesantren immediately became preachers in their respective regions. When they become students they are not ready to interact with others but because when the child arrives to eat there is a culture shock because the child does not understand or does not know that there is a strange culture out there that is owned by his friends, this can affect the mental the child, the child may be inferior, but the child can also adjust if the level of culture shock can be overcome by himself. In the process of socialization, adolescents learn the values, norms and roles in their society. By understanding the values and norms and being able to take a role in society, it shows that the teenager has a good level of conformity because he is able to behave in accordance with social expectations.

\section{ACKNOWLEDGMENT}

We thank you very much to Universitas Negeri Makassar, Faculty of Social Sciences for sponsoring the writing of this article. To the informants, especially the Director of the Pesantren Darul Huffadh, we thank you very much.

\section{REFERENCES}

[1] J. Ja'far, "Problematika Pendidikan Pondok Pesantren di Era Globalisasi," Evaluasi, vol. 2, no. 1, pp. 350-370 http://dx.doi.org/10.32478/evaluasi.v2i1.83

[2] D. R. Gehart, D. Ratliff, and R. R. Lyle, "Qualitative research in family therapy: A substantive and methodological review," Journal of Marital and Family Therapy. 2001. https://doi.org/10.1111/j.1752-0606.2001.tb01162.x

[3] D. Goodley, "Learning difficulties', the social model of disability and impairment: challenging epistemologies," Disabil. Soc., vol. 16, no. 2, pp. 207-231, 2001. https://doi.org/10.1080/09687590120035816

[4] D. Goodley and P. Clough, "Community projects and excluded young people: Reflections on a participatory narrative research approach," Int. J. Incl. Educ., vol. 8, no. 4, pp. 331-351,

2004 https://doi.org/10.1080/1360311042000259139

[5] A. B. Apolo et al., "Summary of the 8th Annual Bladder Cancer Think Tank: collaborating to move research forward," in Urologic Oncology: Seminars and Original Investigations, 2015, vol. 33, no. 2 , pp. 53-64. https://doi.org/10.1016/j.urolonc.2014.06.013

[6] S. Sulistyorini, "Meretas Pendidik Berkualitas dalam Pendidikan Islam." Teras, 2012.

[7] F. A. Yahya, "Problem Manajemen Pesantren, Sekolah Dan Madrasah: Problem Mutu Dan Kualitas Input-proses-output," El-Tarbawi, vol. 8, no. 1, pp. 93-109, 2015. https://doi.org/10.20885/tarbawi.vol8.iss1.art6

[8] Khairuddin, Sosiologi keluarga. Liberty, 2008

[9] P. Chrismawarni, "Pola Asuh di Keluarga ABDI Dalem," J. Ris. Mhs. Bimbing. Dan Konseling, vol. 5, no. 5, 2016.

[10] I. Dewi, "Mengenal bentuk pola asuh orang tua." viewed, 2008.

[11] E. B. Hurlock and J. Penhos, Psicología de la adolescencia. Paidós, 1980

[12] J. W. Santrock and J. W. Santrock, "Psikologi Pendidikan edisi kedua." Kencana Prenada Media Group, 2007.

[13] L. Sriyanti, "Suwardi dan Muna Erawati. 2009," Teor. Belajar.

[14] J. Effendi, "Ernawati. 2005," Profil Organ. Santri, vol. 29.

[15] J. Hamidi and M. Lutfi, "Rethinking Penyelenggaraan Pilkada yang Demokratis dan Partisipatif, dalam Konstitusionalisme Demokrasi (Sebuah Diskursus tentang Pemilu, Otonomi Daerah dan Mahkamah Konstitusi sebagai Kado untuk "Sang Penggembala"e Prof. A. Mukthie Fadjar, SH., MS.), Trans Publ., 2010.

[16] Wawancara Muhammad Fatur, No Title. 2019.

[17] M. J. Franz et al., "Weight-loss outcomes: a systematic review and meta-analysis of weight-loss clinical trials with a minimum 1-year follow-up," J. Am. Diet. Assoc., vol. 107, no. 10, pp. 1755-1767, 2007. https://doi.org/10.1016/j.jada.2007.07.017

[18] E. D. Cahyani, "Sugiyanto. 2008.'The Influence of Peer Group Interaction and Academic Self-Concept on Academic Achievement,"” Anima Indones. Psychol. J., vol. 23, no. 4, p. 308, 2008.

[19] M. P. Yasmadi, "kritik Nurcholish Madjid terhadap pendidikan Islam tradisional," Jakarta Quantum Teach., 2005.

[20] N. Azizah, "Dukungan Orangtua bagi Anak yang Belajar di Pondok Pesantren," 2013.

[21] A. Katz, "Membimbing anak belajar membaca," Surakarta: Arcan, 1997.

[22] M. M. E. Sari, "The Role Of Learning Management Of Islamic Boarding School (Pesantren) In Improvement Of Their Students Religious Tolerance In West Java-Indonesia," Int. J. Innov. Appl. Stud., vol. 19, no. 1, p. 24, 2017. 